\title{
Wild bees as floral visitors to Salvia assurgens (Lamiaceae): a contribution to the pollination ecology of a white-flowered endemic Mexican sage
}

\section{Abejas silvestres visitantes florales de Salvia assurgens (Lamiaceae): aportes a la ecología de la polinización de una salvia mexicana endémica de flores blancas}

\author{
Carlos A. Cultid-Medina',2 (iD, Paola A. González-Vanegas³ (10), Brenda Y. Bedolla-García 4,5 (i)
}

\begin{abstract}
:
Background and Aims: Salvia assurgens (a white-flowered sage) is considered to be a melittophilous species due to its floral architecture. However, there are no current empirical data supporting its assignment to this pollination syndrome. The present study aimed to record the diurnal floral visitors of $S$. assurgens to confirm its characterization as melittophilous and to evaluate which species of bees are potential pollinators.

Methods: We collected wild bee visitors to the flowers of one population of $S$. assurgens in northeastern Michoacán, Mexico, during the summers of 2018 and 2019. We analyzed the pollen loads of each bee species and body area. In addition, we recorded the behavior of some wild bees when visiting flowers of $S$. assurgens.

Key results: Seventeen bee species from three families (Apidae, Halictidae, and Megachilidae) were recorded as floral visitors of $S$. assurgens. Ninety percent of pollen carried by the examined bees belonged to $S$. assurgens. Four species of wild bees were the most frequent visitors, with S. assurgens accounting for $94.2 \%$ of the pollen on their bodies. Notably, these species presented clear differences in the distribution of pollen on their body parts: two of them, Bombus pennsylvanicus sonorus and Megachile sp. 1 accumulated up to $90 \%$ of the pollen on the frons and dorsal area of their thorax. It is most likely that pollen is transferred from these body areas to the stigma of $S$. assurgens.

Conclusions: The present study provides evidence of the melittophilous pollination syndrome of $S$. assurgens. The wild bee richness recorded in this study is as high as that previously reported in studies on floral visitors to Neotropical sages. Finally, our results highlight the usefulness of considering pollen loads to increase our knowledge of Salvia pollination ecology.
\end{abstract}

Key words: grooming, nototribic flowers, pollen manipulation, potential pollinators, safe sites for pollen.

\section{Resumen:}

Antecedentes y Objetivos: Según su arquitectura floral, Salvia assurgens (salvia con flores blancas) ha sido considerada como especie melitófila. Sin embargo, no existen datos empíricos que apoyen la asignación a dicho síndrome de polinización. Este trabajo tuvo como objetivo registrar los visitantes florales diurnos de $S$. assurgens para confirmar su condición melitófila y evaluar qué especies de abejas podrían ser potenciales polinizadores. Métodos: Durante el verano de 2018 y 2019 se colectaron los visitantes florales diurnos en una población de S. assurgens ubicada al noreste de Michoacán, México. Se realizó un análisis descriptivo de las cargas polínicas por especie y áreas corporales de cada visitante floral. Además, se registró el comportamiento de algunos de los visitantes florales sobre las flores.

Resultados clave: Se registraron 17 especies de abejas de tres familias (Apidae, Halictidae y Megachilidae) como visitantes florales de $S$. assurgens. Noventa por ciento de los granos de polen en las cargas polínicas pertenecieron a S. assurgens. Cuatro especies de abejas nativas fueron los visitantes más frecuentes; estas concentraron $94.2 \%$ del polen de S. assurgens y presentaron diferencias en la distribución del polen según el área corporal. Dos de estas especies, Bombus pennsylvanicus sonorus y Megachile sp. 1, concentraron hasta $90 \%$ del polen de $S$. assurgens en su frente y dorso, lugares que hacen más probable la transferencia de polen al estigma de $S$. assurgens.

Conclusiones: Este estudio proporciona una evidencia de la condición melitófila de S. assurgens. De hecho, la riqueza de abejas silvestres registrada en este trabajo fue similar o mayor a la reportada en estudios anteriores sobre visitantes florales de salvias neotropicales. Además, nuestros resultados destacan la utilidad de las cargas de polen para aumentar nuestro conocimiento sobre la ecología de la polinización en Salvia.

Palabras clave: flores nototribicas, limpieza del polen, manipulación del polen, polinizadores potenciales, sitios seguros para el polen.

${ }^{1}$ Instituto de Ecología, A.C., Centro Regional del Bajío, Red de Diversidad Biológica del Occidente Mexicano, Avenida Lázaro Cárdenas 253, 61600 Pátzcuaro, Michoacán, Mexico.

${ }^{2}$ Cátedra-CONACyT, Avenida Insurgentes Sur 1582, 03940 Mexico City, Mexico.

${ }^{3}$ Instituto de Ecología, A.C., Red de Ecología Funcional, Carretera antigua a Coatepec 351, El Haya, 91070 Xalapa, Veracruz, Mexico.

${ }^{4}$ Instituto de Ecología, A.C., Secretaría técnica-colecciones, Centro Regional del Bajío, Avenida Lázaro Cárdenas 253, 61600 Pátzcuaro, Michoacán, Mexico.

${ }^{5}$ Autor para la correspondencia: brenda.bedolla@inecol.mx
Received: September 2, 2020.

Reviewed: November 10, 2020

Accepted by Marie-Stéphanie Samain: February 3, 2021

Published Online first: February 17, 2021.

Published: Acta Botanica Mexicana 128 (2021).

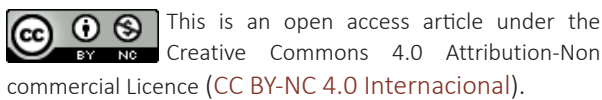

To cite as: Cultid-Medina, C. A., P. A. González-Vanegas and B. Y. Bedolla-García. 2021. Wild bees as floral visitors to Salvia assurgens (Lamiaceae): a contribution to the pollination ecology of a white-flowered endemic Mexican sage. Acta Botanica Mexicana 128: e1785. DOI: https://doi.org/10.21829/ abm128.2021.1785

e-ISSN: 2448-7589 


\section{Introduction}

Mexico has the greatest species richness of Salvia L. subgenus Calosphace (Benth.) Epling (hereinafter referred to as Salvia) in the Americas, with 295 native species of which 243 are endemic (González-Gallegos et al., 2020). Salvia is also the richest angiosperm genus in the country, occurring in almost all vegetation types from sea level to $4000 \mathrm{~m}$ a.s.l. Hence, it is an important element of Mexican biodiversity in addition to having ecological, gastronomic, and medicinal value (e.g., Ramamoorthy and Elliott, 1998; Villaseñor, 2016; Martínez-Gordillo et al., 2017). The New World salvias are easily identified because they present an androecium composed of two monothecal stamens and a modified connective in the form of a lever (staminal lever), which is a specialized structure that aids pollination (Claßen-Bockhoff et al., 2004; Wester and Claßen-Bockhoff, 2006, 2007; Martínez-Gordillo et al., 2017). The anterior part of the staminal lever bears two thecae and is usually located below the upper lip, whereas the posterior part of the staminal lever is sterile and restricts access to the nectar (Claßen-Bockhoff et al., 2004; Celep et al., 2014). Whenever an insect or a bird is searching for nectar, it must push the lever back in order to be loaded with pollen on its head, bill, or back. In a subsequent visit to another flower of the same species, it can then transfer pollen to the stigma (Claßen-Bockhoff et al., 2004).

In general, 'pollination syndrome' refers to the set of morphological traits (mainly related to the corolla) that promote the visitation of a given functional guild of pollinators (Willmer, 2011). At least three pollination syndromes are recognized in Salvia: melittophily (bee pollination), ornithophily (hummingbird pollination), and psychophily (butterfly pollination) (Wester and Claßen-Bockhoff, 2011). A fourth group of sages can be denominated as intermediate or polymorphic because they present floral traits that allow pollination by different functional guilds (e.g., bees and hummingbirds) (Wester and Claßen-Bockhoff, 2011; Kriebel et al., 2019). According to the synopsis proposed by Wester and Claßen-Bockhoff (2011), melittophilous sages have flowers with short corollas (in lateral view) with a lower lip larger than the upper lip, forming a landing platform projected forward or downward, and are usually blue, violet, pink, purple, or creamy-white in color. In contrast, ornitho- philous sages have flowers with longer and narrower tubes and a retrorse, deflexed or reflexed lower lip. Psychophilous sages have a much longer and narrower corolla tube; their apparent radial symmetry results from the petal lobes spreading at a right angle, forming a disc at the end of the corolla tube. Finally, the species denominated intermediate (or polymorphic) tend to have intermediate floral traits between melittophily and ornithophily. In fact, it has been proposed that these species might represent a shift from melittophily to ornithophily or reversion to melittophily (e.g., Fragoso-Martínez et al., 2018), which would evidence critical events in the evolution of the genus, mainly in the New World sages (subgenus Calosphace).

Although the floral shape of Salvia has been extensively used to infer potential functional guilds of pollinators, field data on this topic are scarce or anecdotal. Of the 595 species of Salvia in the New World (González-Gallegos et al., 2020), field data on floral visitors are only available for $11.8 \%$ of these species (70 spp.). These data include information on both potential pollinator and exploiter organisms (e.g., corolla borers, or nectar robbers, and pollen predators, which do not enter through the flower throat). Of these 70 species for which data are available, 25 have been defined as ornithophilous, 38 as melittophilous, and seven as intermediate. In the case of the Mexican salvias, field data on their floral visitors are only available for $13 \%$ of the species, of which 24 are melittophilous, 11 ornithophilous, and six intermediate (Visco and Capon, 1970; Dieringer et al., 1991; Grases and Ramírez, 1998; Ramírez and Martínez, 1998; Chavez-Alonso, 1999; Lara and Ornelas, 2001; Ortiz-Pulido et al., 2002; Arizmendi et al., 2007; Wester and Claßen-Bockhoff, 2007, 2011; Aximoff and Freitas, 2010; Zamora-Carrillo et al., 2011; Espino-Espino et al., 2012, 2014; Lara-Rodríguez et al., 2012; Cuevas-García et al., 2013; Razo, 2015; Ott et al., 2016; Vitali, 2017; Barrionuevo, 2019).

White flowers are unusual in Salvia (González-Gallegos and López-Enríquez, 2016). Of the 295 species in Mexico, only 17 have entirely white flowers, and these are all endemic to the country (González-Gallegos et al., 2018; Zamudio and Bedolla-García, 2018; Bedolla-García et al., 2020a). Twelve of these species are restricted to a particular type locality. Based on the color of the corollas, Ramamoor- 
thy (1984) proposed that the pollination of white-flowered salvias was performed by nocturnal agents, such as moths. However, recent studies indicate that the pollinators of these salvias are not necessarily nocturnal, but may also be melittophilous (e.g., S. albiflora M. Martens \& Galeotti and S. tenorioi Ramamoorthy ex B.L. Turner) (Dieringer et al., 1991) and ornithophilous (e.g., S. madrigalii Zamudio \& Bedolla) (Zamudio and Bedolla-García, 2018). In fact, pollination by moths (i.e., phalaenophily) has only been documented in New World salvias for the Caribbean sage $S$. arborescens Urb. \& Ekman (Reith and Zona, 2016).

In the present study, we examined the floral visitors of $S$. assurgens Kunth, a procumbent perennial herb with entirely white corollas, geographically restricted to the northwestern region of the Trans-Mexican Volcanic Belt (Guanajuato, Michoacán, and Mexico State) (Fig. 1A). Based on floral architecture, Wester and Claßen-Bockhoff (2011) suggested that $S$. assurgens is a melittophilous species, although this has not been supported by field work.
Hence, in this paper, we address two questions: 1) Are wild bees the main diurnal floral visitors of $S$. assurgens? and 2) which wild bee visitors are potential pollinators of this endemic Mexican sage based on pollen load analysis and field observations?

\section{Materials and Methods}

\section{Study site}

Floral visitors were observed in one wild population of Salvia assurgens located on the Cerro Blanco (19³1'58"N, $\left.101^{\circ} 36^{\prime} 3^{\prime \prime} \mathrm{W} ; 2136-2250 \mathrm{~m}\right)$, a hill to the northeast of Pátzcuaro (Michoacán, Mexico) (Fig. 1A). It is a large population with a patchy distribution covering at least 20 $\mathrm{km}^{2}$ ( 200 $\mathrm{m} \times 100 \mathrm{~m}$ ). The vegetation of the Cerro Blanco is composed of native pine-oak woodland, principally Pinus leiophylla Schiede ex Schltdl. \& Cham., P. montezumae Lamb., and Quercus spp.; a reforested area of Cupressus lusitanica Mill. and Pinus devoniana Lindl.; and patches of secondary vegetation with presence of Baccharis

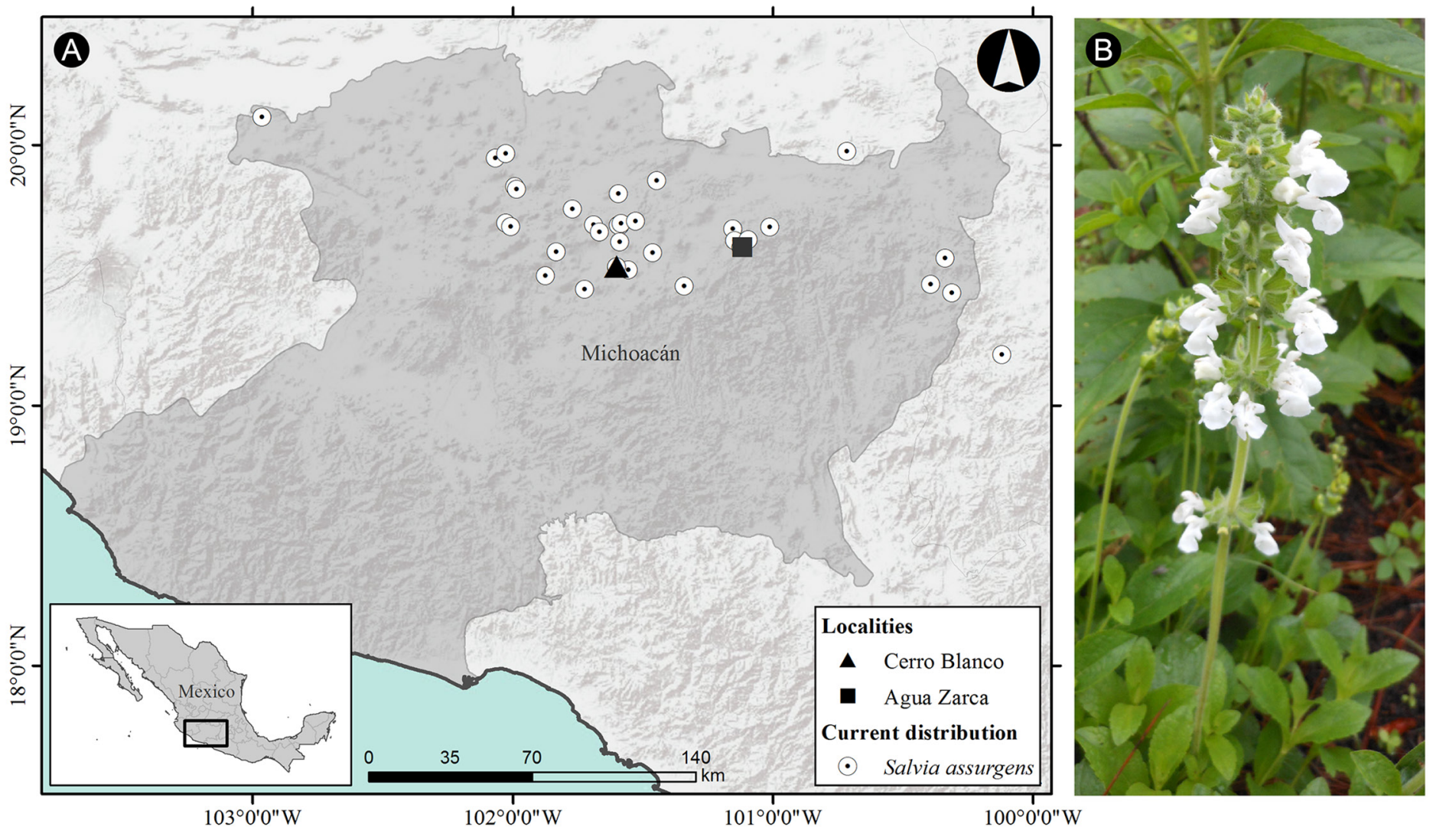

Figure 1: A. distribution of Salvia assurgens Kunth; B. inflorescence of S. assurgens showing its characteristic white flowers on the Cerro Blanco, Pátzcuaro, Michoacán, Mexico. Map: Cultid-Medina, C. A. (2020). Photo: Cultid-Medina, C. A. (2019). 
heterophylla Kunth., Monnina schlechtendaliana D. Dietr., Quercus castanea Née, Roldana sessilifolia (Hook. \& Arn.) H. Rob. \& Brettell, and Rhus aromatica Aiton. There are six Salvia species co-occurring with $S$. assurgens in the study area: Salvia laevis Benth., S. lavanduloides Kunth, S. polystachya Cav., S. purpurea Cav., S. reptans Jacq., and S. tiliifolia Vahl. The flowering peak of S. assurgens (July-August) does not overlap with the flowering of the other sage species.

\section{The delimitation of Salvia assurgens}

Salvia assurgens (sensu stricto) is a procumbent perennial herb of $20-50 \mathrm{~cm}$ tall with terminal, lax inflorescences of 90-150 flowers. The calyx is hirsute with simple and glandular trichomes. The corolla is entirely white, with a ventricose, invaginate tube 6-8 $\mathrm{mm}$ long; the lower lip (8$12 \mathrm{~mm}$ ) is longer than the upper lip $(7.5-8 \mathrm{~mm})$, extending as a platform (Fig. 1B) (Epling, 1939). In this study, we recognize $S$. assurgens in a strict sense. In recent years, $S$. pruniflora Fernald has been synonymized with S. assurgens (González-Gallegos et al., 2014). However, by our criterion, these species differ by the form of the leaves, size of the calyx, color of the flowers, and distribution in Mexico. In addition, the need to re-evaluate the synonymy of these two species has emerged, due to the possibility that they form part of a species complex that requires further study (see González-Gallegos et al., 2020).

\section{Floral visitor sampling}

Sampling was carried out during five days between July and September 2018 and during nine days between 5 and 28 August 2019. To record the floral visitors, we made continuous observations for 3-4 hours between 10:00 and 14:00. Afternoon sampling was not carried out because of afternoon rainfall during these months of the year. Visitors were collected on the flowers using an entomological net and were then preserved with ethyl acetate. Only those floral visitors that perched on the flower and inserted their head into the corolla were collected. In addition, occasional observations were made of a second population (Agua Zarca) located to the south of Morelia in a pine-oak forest $\left(19^{\circ} 36^{\prime} 25.1^{\prime \prime} \mathrm{N}, 101^{\circ} 07^{\prime} 24^{\prime \prime} \mathrm{W} ; 2100 \mathrm{~m}\right)$ (Fig. 1A). Subsequently, the specimens collected were pinned and labeled for taxonomic identification. The keys of Urban (1967), McGinley (1986), Labougle (1990), and Michener et al. (1994) were used to identify the specimens to the lowest taxonomic level possible. Bees of the genus Deltoptila LaBerge and Michener were classified following Ayala (2017). Images of bee specimens were captured using a multifocus digital microscope (Leica Z16 APO, Wetzlar, Germany). Vouchers were deposited in the entomological collection of the Instituto de Ecología, A.C. (IEXA), with a duplicate located in the Centro Regional del Bajío (Pátzcuaro, Michoacán, Mexico).

\section{Pollen load and placement on visitors' bodies}

We collected the pollen deposited on the body surface of the floral visitors (hereinafter pollen loads) using a modification of Beattie's (1971) protocol for establishing the presence of pollen grains of $S$. assurgens and evaluating the pollen richness carried by floral visitors. Pollen was only examined on visitors collected in 2019 because the sampling during this year was more complete and systematic. To ensure that pollen belonged to only one individual, we transported each bee individually in a test tube. Under a light microscope (Zeiss Primo Star, Carl Zeiss Microscopy LLC, NY, USA), the pollen deposited on the following five body areas of the visitors was removed: the dorsal area of the head (frons + vertex), dorsal area of the thorax, ventral area of the thorax, dorsal area of the abdomen, and ventral area of the abdomen. According to the amount of pollen present on the body, one to four glycerine cubes ( $0.027-$ $0.125 \mathrm{~mm}^{3}$ ) were used to collect the pollen from each area. Pollen samples were stored in $0.2 \mathrm{~mm}$ Eppendorf ${ }^{\oplus}$ tubes.

To analyze the pollen, the glycerine cubes were dissolved in distilled water in each Eppendorf ${ }^{\circ}$ tube. Subsequently, acetolysis was performed, and slides were prepared for observation by light microscopy. To quantify pollen loads, pollen grains were counted from three different fields of the slides. Photographs of the pollen grains were used to identify taxa at the family and genus levels, following Kapp et al. (2000), and Martin and Harvey (2017). The presence of pollen grains of $S$. assurgens in the pollen loads was verified by comparison to the pollen obtained from mature flower buds from the same $S$. assurgens populations. The micromorphological characteristics considered to identify the pollen grains of $S$. assurgens are the follow- 
ing: 1) polar region length $(P), 2$ ) equatorial region length $(E), 3)$ length of the largest colpus, and 4) thickness of the exine (Moon et al., 2008; see more details in Bedolla-García et al., 2020b). Additionally, videos of flower visitation by insects were recorded to document in slow motion 1) how visitors approach flowers and 2) their behavior after visiting flowers (e.g., grooming behavior). The videos were recorded with a NIKON D7000 digital SLR camera and edited with iMovie v. 10.1.14 (iMovie, 2020).

\section{Data analysis}

To calculate the frequency of floral visitors to Salvia assurgens, we only used the observations made in 2019. The frequency of each visitor species was calculated as the number of visiting individuals observed per sampling day. To answer the second question (which wild bee visitors are potential pollinators), among the most frequent wild bee species, we compared the following: 1) the relative quantity of pollen grains of $S$. assurgens in the pollen loads on five body areas (sum of the number of pollen grains carried by each individual per wild bee species), 2) the way of approaching flowers, and 3 ) the grooming behavior after floral visitation (when possible). The second and third comparisons were made based on observations in situ.

\section{Results}

\section{Floral visitor richness and frequency}

In the two sampling seasons (2018 and 2019, including Agua Zarca data), we recorded 120 individuals (captured + observed) belonging to 17 bee species in the families Apidae, Halictidae, and Megachilidae (Table 1, Fig. 2). During the 36 sampling hours on the Cerro Blanco, we recorded 109 individuals belonging to 13 bee species. The four most frequent visitors (with three and six flower-visiting records per day) were Megachile (Moureapis) Raw, 2002 sp. 1 (Megachilidae); Lasioglossum pharum Vachal, 1904 (Halictidae); Bombus pennsylvanicus sonorus Say, 1937 (Apidae), and Xylocopa tabaniformis azteca Cresson, 1878 (Apidae) (Table 2).

Table 1: Bee visitors to Salvia assurgens Kunth recorded by locality and year. The number of observed but non-captured individuals are in parentheses. $\mathrm{F}=$ female; $\mathrm{M}=$ male.

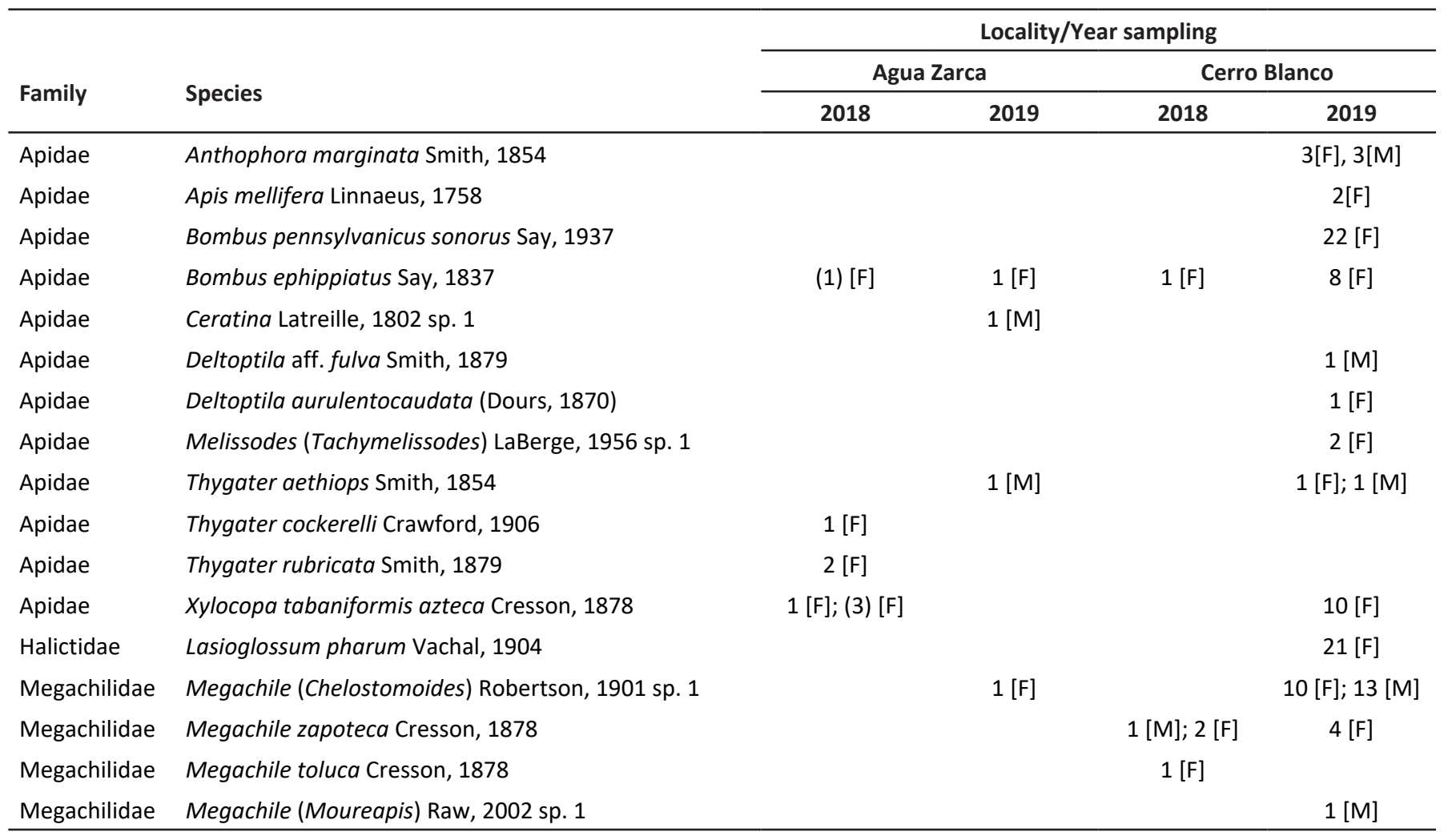



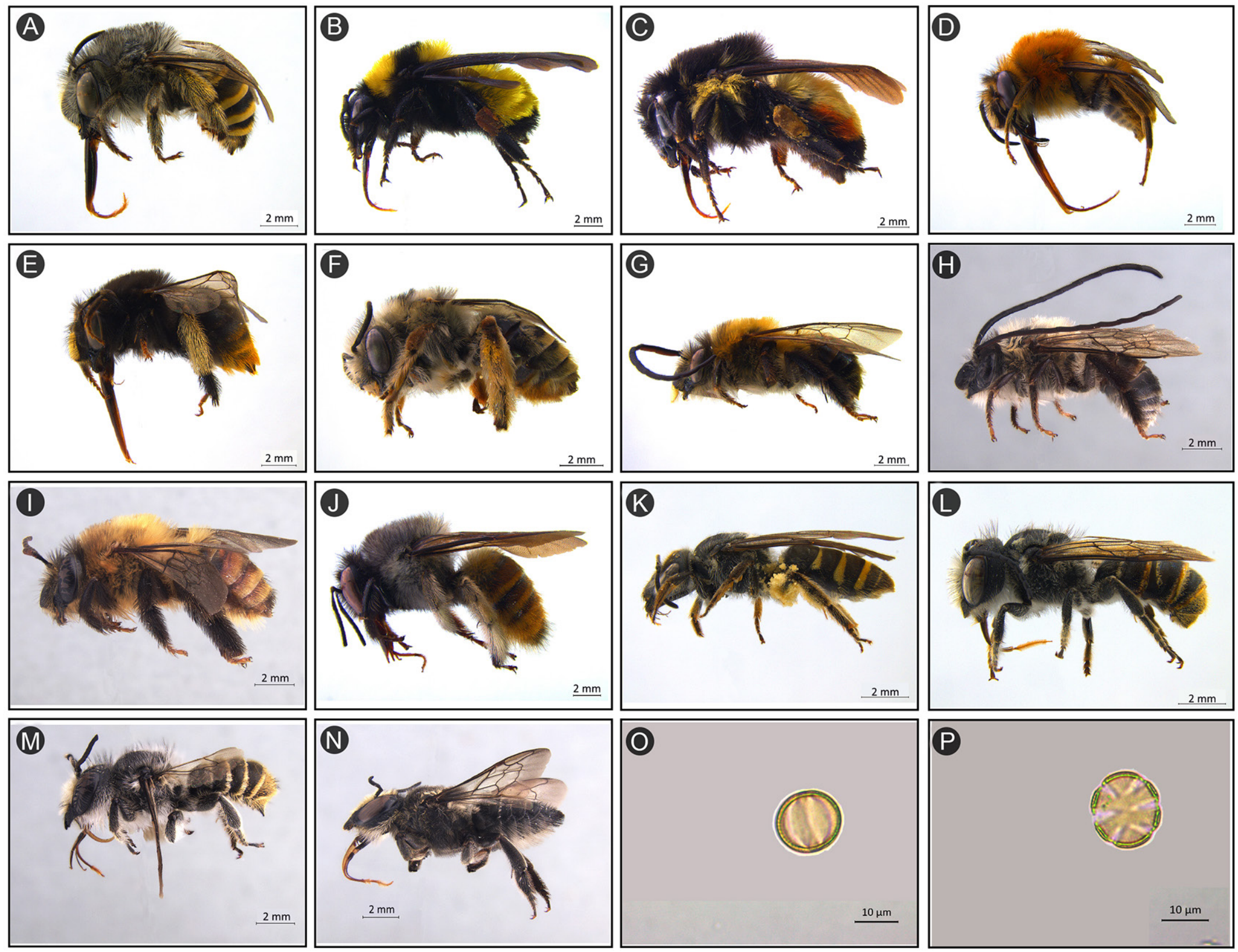

Figure 2: Lateral view of bee species recorded as diurnal floral visitors of Salvia assurgens Kunth: A. Anthophora marginata Smith; B. Bombus pennsylvanicus sonorus Say; C. Bombus ephippiatus Say; D. Deltoptila aff. fulva Smith; E. Deltoptila aurulentocaudata Dours; F. Melissodes (Tachymelissodes) LaBerge sp. 1; G. Thygater aethiops Smith; H. Thygater cockerelli Crawford; I. Thygater rubricata Smith; J. Xylocopa tabaniformis azteca Cresson; K. Lasioglossum pharum Vachal; L. Megachile (Chelostomoides) Robertson sp. 1; M. Megachile zapoteca Cresson; N. Megachile toluca Cresson. Pollen of Salvia assurgens Kunth: O. equatorial view; P. polar view. Not included are photos of Apis mellifera Linnaeus, Ceratina sp. 1, and Megachile (Moureapis) Raw sp. 1. Wild bees photos: Rivera-Gasperín, S., P. González-Vanegas and A. Arriaga-Jiménez (2019); Pollen photos: Castro, M. (2020). 
Table 2: Number of individuals collected per bee species on Salvia assurgens Kunth on the Cerro Blanco, Pátzcuaro, Michoacán, Mexico, showing the capture per sampling day (August, 2019). For social species (Apis mellifera Linnaeus 1758, and Bombus spp.), the number of individuals is included as a measure of incidence but not abundance.

\begin{tabular}{|c|c|c|c|c|c|c|c|c|c|c|}
\hline \multirow{2}{*}{ Species } & \multicolumn{9}{|c|}{ August/Sampling day } & \multirow{2}{*}{ Tota } \\
\hline & 5 & 6 & 8 & 12 & 13 & 15 & 26 & 27 & 28 & \\
\hline Anthophora marginata Smith, 1854 & 1 & 1 & & & 2 & & 2 & & & 6 \\
\hline Bombus pennsy/vanicus sonorous Say, 1937 & 1 & 3 & 4 & 1 & 4 & 2 & 3 & 3 & 1 & 22 \\
\hline Bombus ephippiatus Say, 1837 & & & 2 & & 1 & & 1 & 1 & 3 & 8 \\
\hline Deltoptila aurulentocaudata (Dours, 1870) & & & 1 & & & & & & & 1 \\
\hline Melissodes (Tachymelissodes) LaBerge, 1956 sp. 1 & & & & & 1 & 1 & & & & 2 \\
\hline Thygater aethiops Smith, 1854 & & & 2 & & & & & & & 2 \\
\hline Xylocopa tabaniformis azteca Cresson, 1878 & & 2 & 2 & 2 & 2 & 1 & 1 & & & 10 \\
\hline Megachile (Moureapis) Raw, 2002 sp. 1 & & & & & 1 & & & & & 1 \\
\hline
\end{tabular}

\section{Pollen load and placement on bees' bodies}

The pollen loads of 63 bees belonging to 11 species captured on the Cerro Blanco were examined. Although we obtained pollen-load samples from 109 individuals and 13 species, it was not possible to process all samples due to the start of the COVID-19 quarantine in Mexico. However, 63 individuals are $58 \%$ of the total capture on the Cerro Blanco, and from this sample size, we extracted 20,543 pollen grains, with $90 \%$ belonging to Salvia assurgens (Table 1). The remaining $10 \%$ of the pollen were distributed among six species of Salvia, other genera of Lamiaceae (Nepetoideae) and, in lower frequency, species of Convolvulaceae, Malvaceae, Leguminosae (Caesalpinioideae), and Loranthaceae (Psittacanthinae) (Fig. 3). The four most frequent bee species visiting S. assurgens flowers accounted for over $90 \%$ of the S. assurgens pollen load (Fig. 4); specifically, $57.8 \%$ of the pollen grains were collected from Lasioglossum pharum; $36.4 \%$ from Megachile (Chelostomoides) Robertson, 1901 sp. 1, Bombus pennsylvanicus sonorus, and Xylocopa tabaniformis azteca; 3.6\% from Megachile zapoteca Cresson, 1878; and 1.4\% from B. ephippiatus Say, 1837 (Fig. 4). The rest of the species accounted for less than $2 \%$ of the pollen load from S. assurgens (Fig. 4).

Interspecific differences were observed in how pollen loads from Salvia assurgens were placed on the bees' bodies (Fig. 4). In Lasioglossum pharum and Xylocopa tabaniformis azteca, $57.6 \%$ and $41.8 \%$ of the pollen, respectively, was placed on the ventral area of the abdomen. In contrast, in Megachile (Chelostomoides) sp. 1 and B. pennsylvanicus sonorus, $63 \%$ and $57.4 \%$ of the pollen load, respectively, was found on the head (frons + vertex) (Fig. 4). In addition, the ventral area of L. pharum and the dorsal area of the thorax in Megachile (Chelostomoides) sp. 1 accounted for almost one-fifth of the pollen load (Fig. 4). Although B. ephippiatus was not one of the most frequent visitors to S. assurgens, $93 \%$ of the pollen was found on its head. In M. zapoteca, $70 \%$ of the pollen was found on the ventral area of the abdomen, while in Melissodes Latreille (Tachymelissodes) sp. 1 , pollen was more or less evenly distributed between the ventral area of the thorax and both areas (dorsal and ventral) of the abdomen (39.1\%, $19.2 \%$, and $26.7 \%$, respectively) (Fig. 4).

\section{Video recordings of flower-visiting bees}

In total, 20 minutes of video were recorded in the form of several short $H D$ videos of 0.5 to 3 min long, corresponding to $7 \mathrm{~GB}$ of information. From these videos, the behavior of three bee species visiting Salvia assurgens flowers are described as following. 

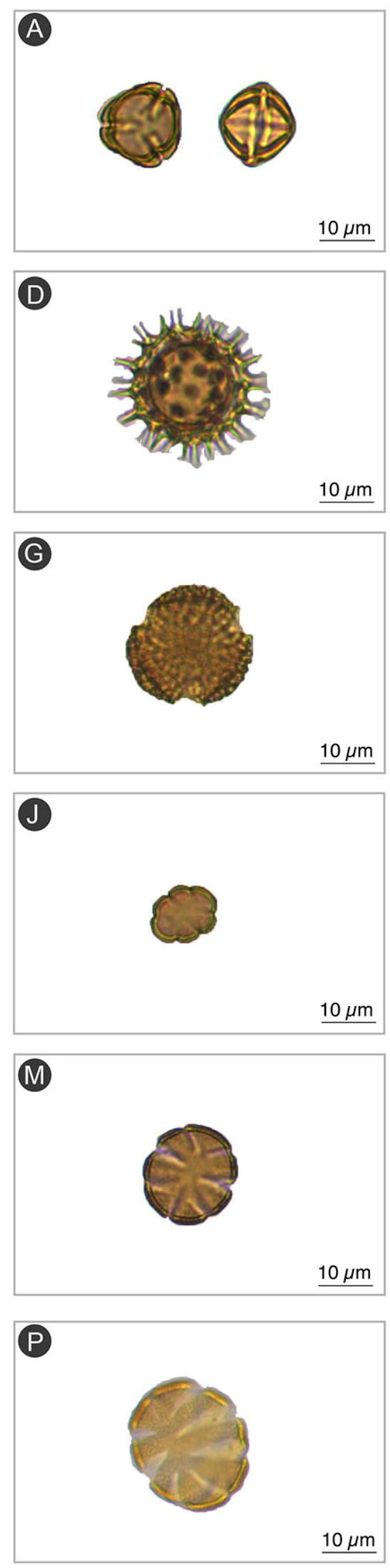
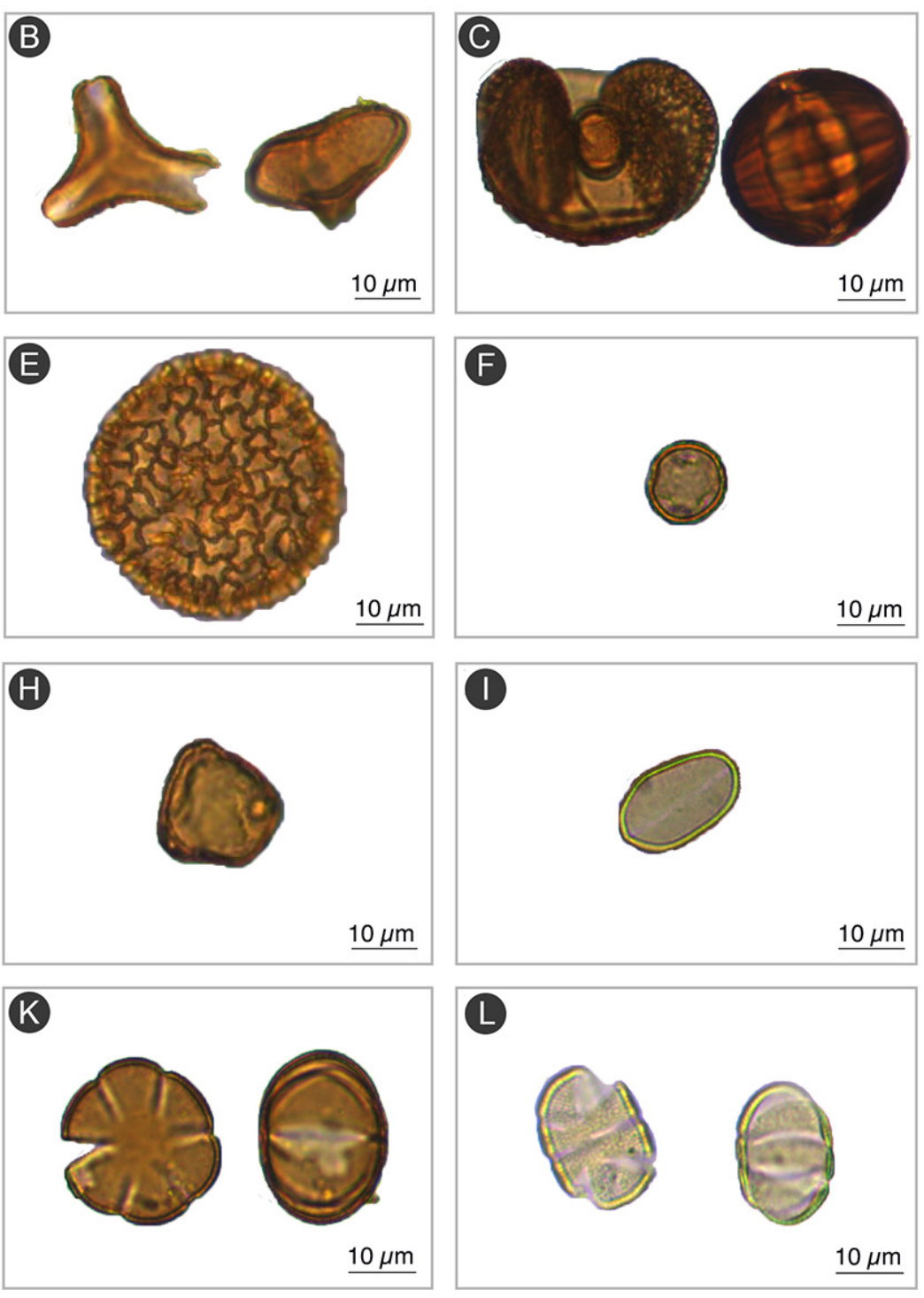

(N)
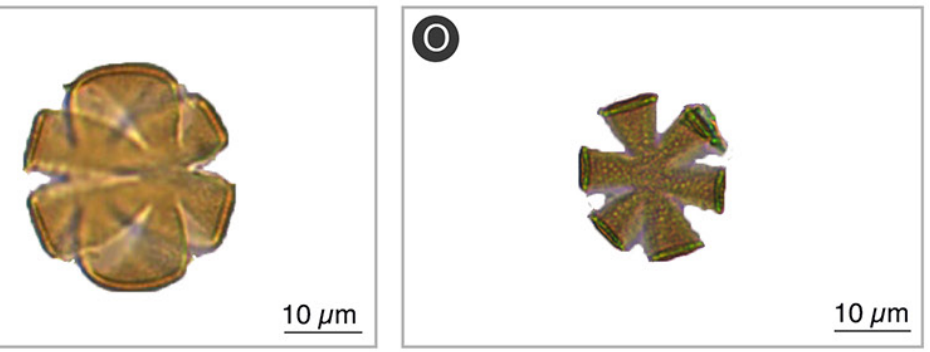

Figure 3: Light microscope micrographs of different taxa pollen grains. A-C and K-L, polar and equatorial views; D-J and M-P, polar view. A Caesalpinioideae (Leguminosae); B. Psittacanthinae (Loranthaceae); C. Pinus sp. (Pinaceae); D. Convolvulaceae or Malvaceae; E. Nyctaginaceae; F. Campanulaceae; G. Acanthaceae; H. Onagraceae; I. Dioscoreales; J. Salvia sp. 1 (Lamiaceae); K. Nepetoideae (Lamiaceae); L. Salvia sp. 2 (Lamiaceae); M. Salvia sp. 3 (Lamiaceae); N. Salvia sp. 4 (Lamiaceae); O. Salvia sp. 5 (Lamiaceae); P. Salvia sp. 6 (Lamiaceae). Photos: Castro, M. (2019-2020). 
Megachile (Chelostomoides) sp. 1

Bombus pennsylvanicus sonorus

Xylocopa tabaniformis azteca

Megachile zapoteca
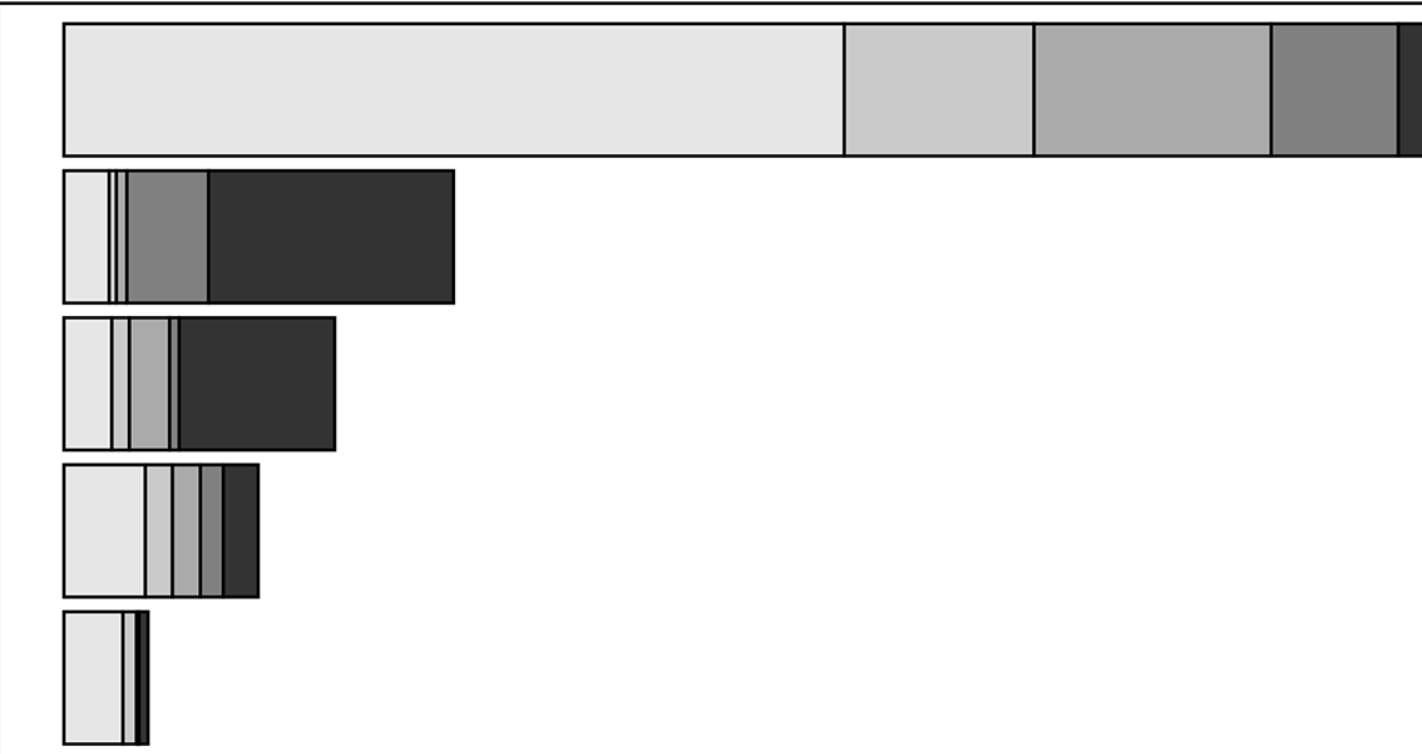

0

20

40

B

Melissodes (Tachymelissodes) sp. I

Anthophora marginata
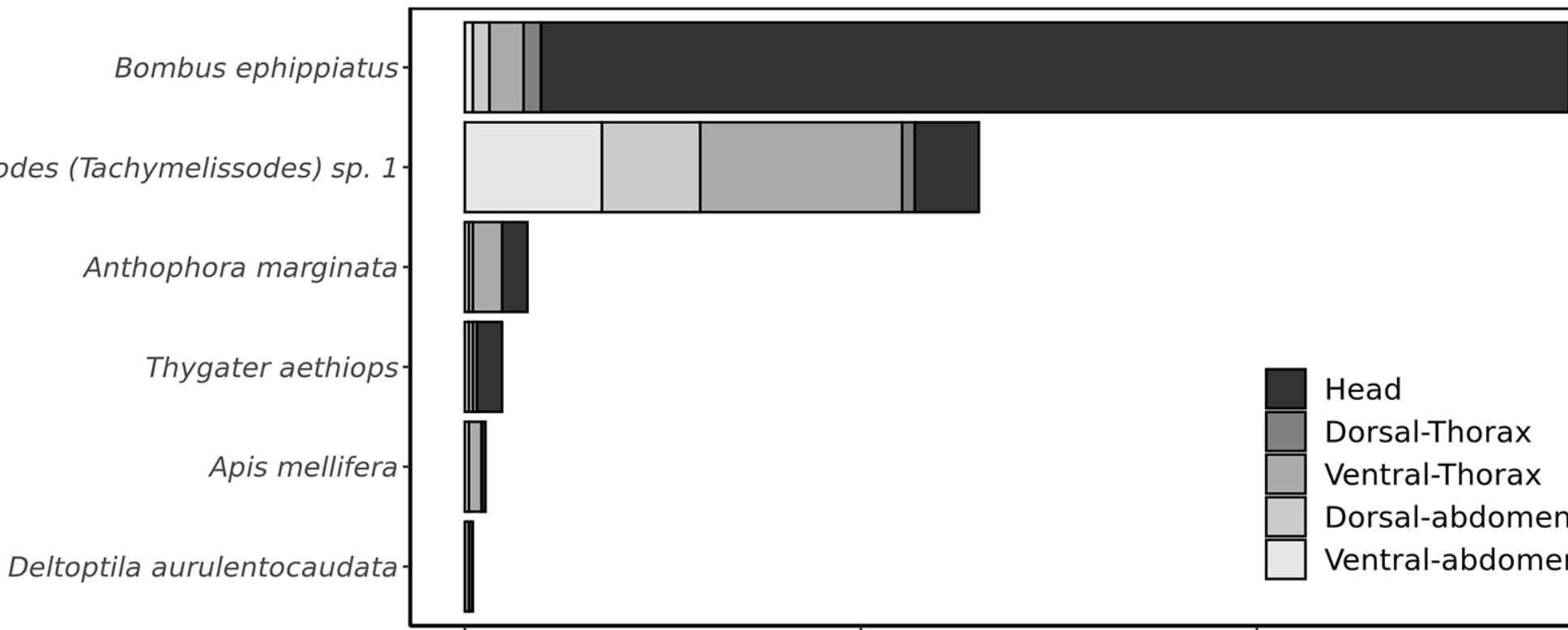

Head

Dorsal-Thorax

Ventral-Thorax

Dorsal-abdomen

Ventral-abdomen

\section{Pollen percentage}

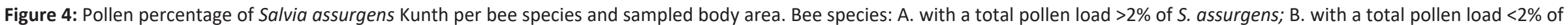
S. assurgens. 


\section{Lasioglossum pharum (see Supplementary video 1)} Lasioglossum pharum flies over the inflorescences of Salvia assurgens in a zigzag pattern. Once the inflorescence has been selected, it perches directly on the lower lip and walks forward, inserting its head into the corolla tube. This action ensures that the bee exerts enough pressure to activate the staminal lever, exposing the anthers located inside the upper lip and enabling direct contact with the dorsal area of the bee's thorax. This contact lasts as long as the bee keeps its head inside the corolla tube. Moreover, during this time, the movements of the bee cause the anthers to continuously rub against the thorax. After finishing sucking nectar, the bee retreats and, at that moment, the stamens retract toward the inside of the upper lip, leaving two clear lines of pollen on the lateral margins of the bee's thorax. These lines run from the posterior to nearly the anterior end of the thorax, passing over the insertion point of the wing.

After the bee withdraws, it stays on the lower lip, leans back slightly (resting on its hind and front legs), and very quickly cleanses the pollen that remains on its thorax. To groom itself, the bee turns its middle legs back above the thorax and combs the pollen forward from the back with the inner edge of the mid-tibiae. In this way, the middle legs appear to collect pollen from the front legs and then move it back toward the hind legs. Thus, much of the pollen is stored on the hind legs and the ventral-basal area of the abdomen. The bee also grooms its head and antennae. Once grooming is complete, the bee passes to another flower. However, observation of the bees collected revealed that the grooming of the thorax is not complete, since a transverse line of pollen remains near the anterior edge of the thorax, just behind the head as a result of the forward grooming movements. Pollen gathering from the anthers was also observed before the bee began grooming: after pulling its head out of the flower, the bee leans back on its middle and hind legs, lifting its head and forelegs toward the inner surface of the upper lip. In that position, the bee appears to collect pollen with its mandibles and front legs. At times, it appears that the bee even inserts part of its mandibles into the lower lip of the flower, perhaps to grab pollen from stamens that have not fully emptied. Thus, the pollen collected is moved to the middle and hind legs and, afterwards, the bee flies to another flower.
Bombus pennsylvanicus sonorus and $B$. ephippiatus (see Supplementary videos 2, 3)

When selecting a flower, Bombus pennsy/vanicus does not perch on the lower lip. Instead, it aims itself toward the flower from the air and inserts its head into the tube of the corolla, while grasping the upper part of the upper lip with its middle legs. The bee then stops moving its wings and hangs on the flower (see Supplementary video 2). Due to its size, only its head has contact with the anthers, which emerge from the upper lip when the bee pushes its head into the corolla tube. Consequently, when the bee finishes sucking and retreats, almost the entire surface of the bee's face is covered in a conspicuous white patch. Based on our study of pollen loads (see above), this patch mainly contains pollen from Salvia assurgens. Unlike Lasioglossum pharum, B. pennsylvanicus does not groom each time it visits a flower. Therefore, $B$. pennsylvanicus can visit several flowers from the same inflorescence or other individuals of $S$. assurgens before grooming. When they occur, grooming movements in B. pennsy/vanicus are very fast and happen when the bee has withdrawn from the flower. To do this, the bee cleans its face with one or both front legs. However, this grooming is not very effective because a large amount of pollen remains on the face of the bee. In the case of Bombus ephippiatus (see Supplementary video 3), a repertoire of behaviors similar to that of $B$. pennsy/vanicus sonorus was observed, with only its head having contact with the floral reproductive structures of $S$. assurgens.

\section{Observations of other floral visitors}

Videos of other species of bees that visited the flowers such as Megachile (Chelostomoides) sp. 1 were obtained (but not included). However, due to the rapid flight of Megachile (Chelostomoides) sp. 1, it was not possible to obtain conclusive evidence of the way it approaches and lands on the flower. Some isolated observations indicate that megachilids do not have direct contact with the flower during pollen extraction: only for a few moments do their heads touch the corolla tube (Cultid-Medina pers. obs.). Moreover, it was not possible to establish the identity of the species or details of its behavioral patterns. Occasionally, visits of some individuals of skipper butterflies (Lepidoptera: Hesperiidae) were recorded. These butterflies perched on 
the flower, but their heads were not observed to come in contact with the upper lip, and the staminal lever was never activated. Both in 2018 and 2019, honeybee (Apis mellifera Linnaeus, 1758) visits were scarce or null. Only two specimens were captured on video inserting their heads into the corolla. They were included in the analysis of pollen loads (Table 1, Fig. 4).

\section{Discussion}

This study presents novel information regarding the richness of floral visitors to $S$. assurgens and the pollen deposition sites on the body of the bee visitors, contributing to the knowledge of Salvia-bee interactions and the pollination ecology of Salvia assurgens, a white-flowered sage. We found that, during the day, S. assurgens is almost exclusively visited by bees (which touch the anthers and stigma) and is certainly pollinated by them. The number of bee visitors to $S$. assurgens is close to or higher than the reported number of bee visitors (per locality) to other sages of the New World, including sages with white or cream flowers (Dieringer et al., 1991; Espino-Espino et al., 2012, 2014; Celep et al., 2014). It was noteworthy that $90 \%$ of the overall pollen load on the bee visitors belonged to S. assurgens, and more than $70 \%$ of the pollen carried by five out of the thirteen encountered species was from S. assurgens. However, a clear difference was observed in the distribution of pollen grains on the bodies of different bee species, much of which was placed in areas that could be considered safe sites as defined by Koch et al. (2017). These findings suggest a more complex picture of the relative contribution of bee visitors to the floral ecology of $S$. assurgens.

Bees of the families Megachilidae and Apidae (mainly bumble bees, Bombus spp., and carpenter bees, Xylocopa spp.) have formerly been reported as floral visitors and proposed as potential pollinators of Salvia spp. (Dieringer et al., 1991; Vicens et al., 1993; Fernández-Alonso, 2008; Zavortink and Shanks, 2008; Cairampoma and Martel, 2012; Espino-Espino et al., 2014). For white-flowered salvias, in particular Dieringer et al. (1991) recorded B. ephippiatus formosus (according to Labougle 1990, a synonym of $B$. ephippiatus Say 1837), and X. tabaniformis melanosoma O'Brien and Huerd 1963 on S. tenorioi and S. albiflora, respectively. Therefore, the visits to the white-flowered $S$. assurgens recorded herein of two species of Bombus, four species of Megachile, and Xylocapa tabaniformis azteca are consistent with the floral visitors expected for beepollinated salvias.

To answer the question regarding which bee visitors are the potential primary pollinators of $S$. assurgens, it was necessary to study several characteristics of the bees, including 1) where pollen loads are placed on their bodies, 2) their grooming behavior after flower visitation, and 3) floral constancy (i.e., a behavior exhibited by many pollinators wherein their visits are largely restricted to a single floral type). Pollen loaded on visitors will only effectively pollinate flowers if it can reach the surface of the stigma (Dafni, 1992) and, as previously stated, the stigma and anthers of $S$. assurgens flowers are hidden by an upper lip at a distance far from than the nectar (nototribic flower). Thus, for effective pollen deposition on the stigma of this type of flower, the pollen has to be on the dorsum of the bees (Müller, 1996; Claßen-Bockhoff et al., 2004; Danforth et al., 2019). Based on our studies of pollen loads, $B$. pennsylvanicus sonorus and Megachile (Chelostomoides) Robertson sp. 1 could make a more significant contribution to the pollination of $S$. assurgens than L. pharum and $X$. tabaniformis azteca, because, in the first two mentioned species, the pollen was primarily placed on the head (a possible safe site, see Portman et al., 2019) (Fig. 4). In this case, the pollen can more easily come into contact with the anther surface and pollinate the flower, whereas in L. pharum and $X$. tabaniformis azteca, the pollen was mostly placed over the ventral area of the abdomen, making contact with the stigma less likely. In addition to the appropriate placement of pollen, the bees must be large enough to touch the anthers as well as the stigma. All the bees recorded visiting S. assurgens, except L. pharum, have the appropriate size to reach the stigma (e.g., see Supplementary video 1 vs. Supplementary videos 2-3). Secondly, the pollen available to be deposited on the stigma will depend on the grooming efficiency of the bee as well as the time of grooming (Thomson and Thomson, 1992). Bombus pennsy/vanicus sonorus grooms after visiting several flowers (see Supplementary video 2 ), while $L$. pharum (see Supplementary video 1 ) and $X$. tabaniformis azteca groom after visiting a single flower. During this process, the latter two bees manipulate 
the pollen and place it on the ventral area of their body, where it may no longer be available for the pollination process (Thorp, 2000). Thus, L. pharum and $X$. tabaniformis azteca are poor candidates as potential pollinators of $S$. assurgens.

Finally, floral constancy could be of critical importance for the reproductive success of plants because it minimizes pollen loss and prevents the stigma from clogging with foreign pollen (Goulson, 2010). However, the existence of floral constancy is a controversial topic, with very heterogeneous evidence (see Willmer, 2011). Although our results do not allow us to infer or to present direct evidence of floral constancy, the analysis of the pollen loads does suggest that some bees, such as $B$. pennsylvanicus sonorus and $L$. pharum, show a degree of temporal fidelity to $S$. assurgens (Fig. 4), probably because of its conspicuous floral display and dominance in the plant community of our study site. Moreover, bees such as bumble bees and carpenter bees tend to visit patches of flowering plants on a recurrent basis, as long as they obtain rewards (Goulson, 2010; Wilson and Carril, 2016). In the case of bumble bees, they have a high learning capacity, allowing them to remember a patch of flowering plants and synchronize with the availability of floral resources (Goulson, 2010).

As previously stated, Salvia assurgens pollen predominates in the pollen loads of bee species that visit it. This may reflect the phenology of $S$. assurgens in the study area. The Cerro Blanco is a mountain area reforested less than 50 years ago, with open or semi-open areas where different herbaceous species and shrubs proliferate. However, in August (summer), few plant species are in bloom, and S. assurgens is one of the few species that has its flowering peak in midsummer, much earlier than other species of Salvia in the study area. Furthermore, the studied population is one of the largest that has been observed in Trans-Mexican Volcanic Belt region, with a relatively high density of individuals. Elsewhere, S. assurgens individuals have been observed as more or less scattered. Thus, at the time of sampling, the $S$. assurgens population of the Cerro Blanco may have constituted a vital resource for bees in terms of pollen and nectar. The foraging activity of bees can be strongly influenced by the availability (spatial and temporal) of floral resources (Willmer and Stone, 2004).
Thus, the phenological circumstances and potentially high (and aggregate) resource supply offered by S. assurgens on the Cerro Blanco during August 2019 appeared to have promoted "floral constancy" (or fidelity) in the behavior of visiting bees at least in the most frequent bee species.

Although our study of the diurnal floral visitors of $S$. assurgens was based on a single population (due to logistical reasons), the study area (Cerro Blanco) offered an ideal setting to obtain baseline information on some aspects of Salvia-bee interactions. As there was a relatively large patch of $S$. assurgens and few other herbaceous flowering species, it was possible to document the potential role of flower visitors to $S$. assurgens. This study also highlights the usefulness of analyzing pollen loads in plant-pollinator interaction studies. However, it is necessary to carry out further complementary studies to evaluate floral display and reproductive success according to the taxonomic and functional richness of floral visitors. Finally, to establish whether S. assurgens visitors exhibit any degree of floral constancy, further studies are required to evaluate how the frequency of visits changes according to the time of day and how the richness of floral visitors and amount of loaded pollen change when other species growing alongside $S$. assurgens come into flower.

\section{Conclusions}

The population of Salvia assurgens on the Cerro Blanco is visited by a rich community of bees. The analysis of the pollen loads and observations in the field enabled the detection of differences in the potential contribution of visiting bees to the pollination of $S$. assurgens. These differences seem to be influenced by the behavior of some bee species, including the gathering or deposition of pollen on their bodies and their grooming habits. The deposition or collection of pollen on the safe sites of their body probably does not favor pollination, whereas the deposition of pollen on the dorsal part of the head, as occurs in B. pennsylvanicus sonorus, Megachile (Chelostomoides) sp. 1 , and B. ephippiatus, appears to favor the pollination of S. assurgens, given its floral morphology. Thus, these latter species could be more significant pollinators. This study confirms the usefulness of analyzing pollen loads to increase our knowledge of the pollination ecology of Salvia. 


\section{Author contributions}

CACM and BYBG conceived the study design and carried out the field and lab work. BYBG realized the quantification and the taxonomic determination of pollen grains. PAGV realized the taxonomic determination of wild bees. CACM y BYBG carried out the data analysis. All authors contributed to the discussion and approval of the final manuscript.

\section{Funding}

This study was supported by the Consejo Nacional de Ciencia y Tecnología (CONACYT) to Carlos A. Cultid-Medina and Brenda Bedolla-García through the Sistema Nacional de Investigadores (SNI) (No. 38370 and No. 80655, respectively). It was carried out within the framework of the research activities of the CONACYT - INECOL Chair Project No. 673 "Etnobiología, interacciones biológicas y restauración ecológica en el Centro - Occidente de México", in the research line of in Biodiversity and Biological Interactions led by Cultid-Medina.

\section{Acknowledgments}

We are grateful to Rosalía Fernández Tarrio and Luis Rey Flores for editing Figures 2 and 3, respectively. Teresa Guerrero, Daniel Madrigal, Victor Reyes, and Mayra Castro helped with the field and laboratory work. Special thanks to Victor Reyes for helping with the video recording in the field, to Sara Lariza Rivera-Gasperín and Alfonsina Arriaga-Jiménez for the wild bee photos. Finally, thanks to the "Red de Ecoetología" (Instituto de Ecología, A.C.-INECOL, Xalapa, Veracruz) for access to the multifocus digital microscope (Leica Z16 APO, Wetzlar, Germany) used for taking the wild bee photos.

\section{Literature cited}

Arizmendi, M. del C., C. Monterrubio-Solís, L. Juárez, I. FloresMoreno and E. López-Saut. 2007. Effect of the presence of nectar feeders on the breeding success of Salvia mexicana and Salvia fulgens in a suburban park near México City. Biological Conservation 136(1): 155-158. DOI: https://doi. org/10.1016/j.biocon.2006.11.016

Aximoff, I. A. and L. Freitas. 2010. Is pollen removal or seed set favoured by flower longevity in a hummingbird-pollinated
Salvia species? Annals of Botany 106(3): 413-419. DOI: https://doi.org/10.1093/aob/mcq141

Ayala, R. 2017. Las abejas del género Deltoptila (Apidae: Apinae). In: Escobedo, N., E. Enríquez, P. Landaverde, O. Martínez, A. Armas, A. Marroquín, L. Hernández, M. Medina, M. Guzmán, R. Zepeda, T. Gruber, S. Straffon, D. Escobar, C. Méndez and Q. Casiá. Memorias X Congreso Mesoamericano sobre Abejas Nativas, Noviembre 20-24, 2017. La Antigua, Guatemala. pp. 208-213.

Barrionuevo, N. 2019. Dicogamia, sistema reproductivo, producción de néctar y comportamiento de los polinizadores en Salvia stachydifolia Benth., una especie de polinización mixta. Tesis de licenciatura. Facultad de Ciencias Exactas, Físicas y Naturales, Universidad de Córdoba. Córdoba, Argentina. $19 \mathrm{pp}$.

Beattie, A. J. 1971. A technique for the study of insect-borne pollen. Pan-Pacific Entomologist 47(1): 82.

Bedolla-García, B. Y., S. Zamudio and H. A. Castillo-Gómez. 2020a. Salvia huastecana (Lamiaceae), a new species from San Luis Potosí, Mexico. Phytotaxa 433(1): 1-8. DOI: https://doi. org/10.11646/phytotaxa.433.1.1

Bedolla-García, B. Y., M. Castro-Morales and C. A. Cultid-Medina. 2020b. Comparative assessment of pollen micromorphology of Salvia assurgens (Lamiaceae), an endemic sage from Mexico. Phytotaxa 458(3): 183-194. DOI: https://doi. org/10.11646/phytotaxa.458.3.1

Cairampoma, L. and C. Martel. 2012. Floral visitors in Salvia rhombifolia Ruiz \& Pavon (Lamiaceae) in Lima, Peru: a beepollinated species. The Biologist 10(2): 97-103.

Celep, F., Z. Atalay, F. Dikmen, M. Doğan and R. Claßen-Bockhoff. 2014. Flies as pollinators of melittophilous Salvia species (Lamiaceae). American Journal of Botany 101(12): 21482159. DOI: https://doi.org/10.3732/ajb.1400422

Chavez-Alonso, C. L. A. 1999. Ecología de polinización de Salvia mexicana. Tesis de licenciatura. Facultad de Ciencias, Universidad Nacional Autónoma de México. Cd. Mx., México. $86 \mathrm{pp}$.

Claßen-Bockhoff, R., T. Speck, E. Tweraser, P. Wester, S. Thimm and M. Reith. 2004. The staminal lever mechanism in Salvia L. (Lamiaceae): a key innovation for adaptive radiation? Organisms, Diversity and Evolution 4(3): 189-205. DOI: https://doi.org/10.1016/j.ode.2004.01.004 
Cuevas-García, E., A. Alcalá-Guerra, Y. E. Baños-Bravo and A. Flores-Palacios. 2013. Biología reproductiva y robo de néctar en Salvia gesneriflora (Lamiaceae) y sus consecuencias en el éxito reproductivo. Botanical Sciences 91(3): 357-362. DOI: https://doi.org/10.17129/botsci.14

Dafni, A. 1992. Pollination ecology: a practical approach. Oxford University Press. New York, USA. 250 pp.

Danforth, B. N., R. L. Minckley, J. L. Neff and F. Fawcett. 2019. The solitary bees: biology, evolution, conservation. Princeton University Press. Princeton, USA. 472 pp.

Dieringer, G., T. P. Ramamoorthy and P. Tenorio Lezama. 1991. Floral visitors and their behaviour to sympatric Salvia species (Lamiaceae) in Mexico. Acta Botanica Mexicana 13: 75-83. DOI: https://doi.org/10.21829/abm13.1991.609

Epling, C. 1939. A revisión of Salvia subgenus Calosphace. Feddes Repertorium Specierum Novarum Regni Vegetabilis 110: 1-383.

Espino-Espino, J., Y. E. Baños and E. Cuevas. 2012. Biología reproductiva y visitantes florales de dos especies de Salvia con síndrome de polinización por aves y abejas. Ciencia Nicolaita 55: 52-60.

Espino-Espino, J., F. Rosas and E. Cuevas-García. 2014. Variación temporal de visitantes florales en dos especies simpátricas de Salvia con floración simultánea y síndrome de polinización contrastante. Revista Mexicana de Biodiversidad 85(1): 161166. DOI: https://doi.org/10.7550/rmb.35248

Fernández-Alonso, J. L. 2008. Estudios en Labiatae - vi. hibridación en el género Salvia en Colombia y su interés horticultural. Caldasia 30(1): 21-48.

Fragoso-Martínez, I., M. Martínez-Gordillo, G. A. Salazar, F. Sazatornil, A. A. Jenks, M. R. García-Peña, G. BarreraAveleida, S. Benitez-Vieyra, S. Magallón, G. CornejoTenorio and C. Granados-Mendoza. 2018. Phylogeny of the Neotropical sages (Salvia subg. Calosphace; Lamiaceae) and insights into pollinator and area shifts. Plant Systematics and Evolution 304: 43-55. DOI: https://doi.org/10.1007/ s00606-017-1445-4

González-Gallegos, J. G., B. Y. Bedolla-García, G. Cornejo-Tenorio, J. L. Fernández-Alonso, I. Fragoso-Martínez, M. R. GarcíaPeña, R. M. Harley, B. Klitgaard, M. J. Martínez-Gordillo, J. R. I. Wood, S. Zamudio, S. Zona and C. C. Xifreda. 2020. Richness and distribution of Salvia subg. Calosphace
(Lamiaceae). International Journal of Plant Sciences 181(8): 831-856. DOI: https://doi.org/10.1086/709133

González-Gallegos, J. G., A. Castro-Castro, V. Quintero-Fuentes, M. E. Mendoza-López and E. de Castro-Arce. 2014. Revisión taxonómica de Lamiaceae del occidente de México. Ibugana 7: 3-545.

González-Gallegos, J. G., I. Fragoso-Martínez, G. GonzálezAdame, E. Martínez-Ambriz and I. L. López-Enríquez. 2018. Salvia ozolotepecensis, S. patriciae and S. sirenis (Lamiaceae), three new species from Miahuatlán district, Oaxaca, Mexico. Phytotaxa 362(2): 143-159. DOI: https:// doi.org/10.11646/phytotaxa.362.2.2

González-Gallegos, J. G. and I. L. López-Enríquez. 2016. Salvia wixarika (Lamiaceae), a new species from Jalisco, Mexico, and novelties on Mexican Salvia with white corollas. Phytotaxa 260(2): 176-184. DOI: https://doi.org/10.11646/ phytotaxa.260.2.7

Goulson, D. 2010. Bumblebees: behaviour, ecology, and conservation. Oxford University Press. New York, USA. 317 pp.

Grases, C. and N. Ramírez. 1998. Biología reproductiva de cinco especies ornitófilas en un fragmento de bosque caducifolio secundario en Venezuela. Revista de Biología Tropical 46(4): 1095-1108.

iMove. 2020. iMove v10.1.14. (C) 1999-2001, 2003-2020 Apple Inc. All rights reserved. Cupertino, USA. https://apps.apple. com/us/app/imovie/id408981434?mt=12

Kapp, R. O., O. K. Davis and J. E. King. 2000. Pollen and Spores. 2nd ed. American Association of Stratigraphic Palynologist Foundation. Texas, USA. 279 pp.

Koch, L., K. Lunau and P. Wester. 2017. To be on the safe site Ungroomed spots on the bee's body and their importance for pollination. PloS ONE 12(9): e0182522. DOI: https://doi. org/10.1371/journal.pone.0182522

Kriebel, R., B. T. Drew, C. P. Drummond, J. G. González-Gallegos, F. Celep, M. M. Mahdjoub, J. P. Rose, X. Chun-Lei, H. GuoXiong, J. B. Walker, E. M. Lemmon, A. R. Lemmon and K. J. Sytsma. 2019. Tracking temporal shifts in area, biomes, and pollinators in the radiation of Salvia (sages) across continents: leveraging anchored hybrid enrichment and targeted sequence data. American Journal of Botany 106(4): 573-597. DOI: https://doi.org/10.1002/ajb2.1268 
Labougle, J. M. 1990. Bombus of México and Central America (Hymenoptera, Apidae). Kansas University Science Bulletin 54(3): 35-73.

Lara, C. and J. F. Ornelas. 2001. Preferential nectar robbing of flowers with long corollas: experimental studies of two hummingbird species visiting three plant species. Oecologia 128: 263-273. DOI: https://doi.org/10.1007/ s004420100640

Lara-Rodríguez, N. Z., R. Díaz-Valenzuela, V. Martínez-García, E. Mauricio-Lopéz, S. Anaid-Díaz, O. I. Valle, A. D. Fisher-de León, C. Lara and R. Ortiz-Pulido. 2012. Redes de interacción colibrí-planta del centro-este de México. Revista Mexicana de Biodiversidad 83(2): 569-577. DOI: http://dx.doi. org/10.22201/ib.20078706e.2012.2.965

Martin, A. C. and W. J. Harvey. 2017. The Global Pollen Project: a new tool for pollen identification and the dissemination of physical reference collections. Methods in Ecology and Evolution 8(7): 892-897. DOI: https://doi.org/10.1111/2041210X.12752

Martínez-Gordillo, M. J., B. Bedolla-García, G. Cornejo-Tenorio, I. Fragoso-Martínez, M. R. García-Peña, J. G. GonzálezGallegos, S. I. Lara-Cabrera and S. Zamudio. 2017. Lamiaceae de México. Botanical Sciences 95(4): 780-806. DOI: https:// doi.org/10.17129/botsci.1871

McGinley, R. J. 1986. Studies of Halictinae (Apoidea: Halictidae), I: revision of New World Lasioglossum Curtis. Smithsonian Contributions to Zoology 429: 1-294. DOI: https://doi. org/10.5479/si.00810282.429

Michener, C. D., R. J. McGinley and B. N. Danforth. 1994. The bee genera of North and Central America: (Hymenoptera: Apoidea). Smithsonian Institution Press. Washington, USA. 209 pp.

Moon, H. K., S. Vinckier, J. B. Walker, E. Smets and S. Huysmans. 2008. A search for phylogenetically informative pollen characters in the subtribe Salviinae (Mentheae: Lamiaceae). International Journal of Plant Sciences 169(3): 455-471. DOI: https://doi.org/10.1086/526463

Müller, A. 1996. Convergent evolution of morphological specializations in Central European bee and honey wasp species as an adaptation to the uptake of pollen from nototribic flowers (Hymenoptera, Apoidea and Masaridae).
Biological Journal of the Linnean Society 57(3): 235-252. DOI: https://doi.org/10.1006/bijl.1996.0013

Ortiz-Pulido, R., A. Townsend, M. B. Robbins, R. Díaz, A. G. Navarro-Sigüenza and G. Escalona-Segura. 2002. The Mexican Sheartail (Doricha eliza): Morphology, behavior, distribution, and endangered status. The Wilson Journal of Ornithology 114(2): 153-160. DOI: https://doi. org/10.1676/0043-5643(2002)114[0153:TMSDEM]2.0. $\mathrm{CO} ; 2$

Ott, D., P. Hühn and R. Claßen-Bockhoff. 2016. Salvia apiana-A carpenter bee flower? Flora 221: 82-91. DOI: https://doi. org/10.1016/j.flora.2015.12.008

Portman, Z. M., M. C. Orr and T. Griswold. 2019. A review and updated classification of pollen gathering behavior in bees (Hymenoptera, Apoidea). Journal of Hymenoptera Research 71: 171-208. DOI: https://doi.org/10.3897/jhr.71.32671

Ramamoorthy, T. P. 1984. Notes on Salvia (Labiatae) in Mexico, with three new species. Journal of the Arnold Arboretum 65: 135-143.

Ramamoorthy, T. P. and M. Elliot. 1998. Lamiaceae de México: diversidad, distribución, endemismo y evolución. In: Ramamoorthy, T. P., R. Bye, A. Lot and J. Fa (eds.). Diversidad Biológica de México: Orígenes y Distribución. Instituto de Biología, Universidad Nacional Autónoma de México. Estado de México, México. pp. 501-525.

Ramírez, E. and E. Martínez. 1998. Resources foraged by Euglossa atroveneta (Apidae: Euglossinae) at Unión Juárez, Chiapas, Mexico. A palynological study of larval feeding. Apidologie 29: 347-359.

Razo, A. E. 2015. Abejas silvestres (Hymenoptera: Apoidea: Anthophila) y sus interacciones con la flora en la Sierra de Quila, Tecolotlán, Jalisco. Tesis de maestría. Centro Universitario de Ciencias Biológicas y Agropecuarias, Universidad de Guadalajara. Guadalajara, Jalisco, México. 129 pp.

Reith, M. and S. Zona. 2016. Nocturnal flowering and pollination of a rare Caribbean sage, Salvia arborescens (Lamiaceae). Neotropical Biodiversity 2(1): 115-123. DOI: https://doi.org /10.1080/23766808.2016.1230461

Thomson, J. D. and B. A. Thomson. 1992. Pollen presentation and viability schedules in animal-pollinated plants: 
consequences for reproductive success. In: Wyatt, $R$. (ed.). Ecology and Evolution of Plant Reproduction: New Approaches. Chapman \& Hall. New York, USA. Pp. 1-24.

Thorp, R. W. 2000. The collection of pollen by bees. Plant Systematics and Evolution 222(1/4): 211-223. DOI: https:// doi.org/10.1007/BF00984103

Urban, D. 1967. As espécies do gênero Thygater Holmberg, 1884 (Hymenoptera, Apoidea). Boletim da Universida de Federal do Paraná (Zoologia) 2(12): 177-307.

Vicens, N., J. Bosch and M. Blas. 1993. Análisis de los nidos de algunas Osmia (Hymenoptera, Megachilidae) nidificantes en cavidades preestablecidas. Orsis 8: 41-52.

Villaseñor, J. L. 2016. Checklist of the native vascular plants of Mexico. Revista Mexicana de Biodiversidad 87(3): 559-902. DOI: http://dx.doi.org/10.1016/j.rmb.2016.06.017

Visco, F. J. and B. Capon. 1970. Pollination Mechanisms in Three Species of Salvia Native to Southern California. Aliso: A Journal of Systematic and Evolutionary Botany 7(2): 231242. DOI: https://doi.org/10.5642/aliso.19700702.11

Vitali, A. 2017. Macrofauna asociada a cultivos de chía (Salvia hispanica L., Lamiaceae) en el sudeste de Santa Fe. Tesis de licenciatura. Facultad de Ciencias Agrarias, Universidad Nacional de Rosario. Rosario, Argentina. 63 pp.

Wester, P. and R. Claßen-Bockhoff. 2006. Hummingbird pollination in Salvia haenkei (Lamiaceae) lacking the typical lever mechanism. Plant Systematic and Evolution 257: 133-146. DOI: https://doi.org/10.1007/s00606-005-0366-9

Wester, P. and R. Claßen-Bockhoff. 2007. Floral Diversity and Pollen Transfer Mechanisms in Bird-pollinated Salvia Species. Annals of Botany 100(2): 401-421. DOI: https://doi. org/10.1093/aob/mcm036
Wester, P. and R. Claßen-Bockhoff. 2011. Pollination Syndromes of New World Salvia Species with Special Reference to Bird Pollination. Annals of the Missouri Botanical Garden 98(1): 101-155. DOI: https://doi.org/10.3417/2007035

Willmer, P. 2011. Pollination and floral ecology. Princeton University Press. Princeton, UK. 778 pp.

Willmer, P. G. and G. N. Stone. 2004. Behavioral, Ecological, and Physiological Determinants of the Activity Patterns of Bees. In: Slater, P. J. B., J. S. Rosenblatt, C. T. Snowdon, T. J. Roper, H. J. Brockmann and M. Naguib (eds.). Advances in the Study of Behavior 34: 347-466. DOI: https://doi. org/10.1016/S0065-3454(04)34009-X

Wilson, J. S. and O. Carril. 2016. The Bees in Your Backyard: A Guide to North America's Bees. Princeton University Press. Princeton, USA. 288 pp.

Zamora-Carrillo, M., G. D. Amat-García and J. L. FernándezAlonso. 2011. Estudio de las visitas de las moscas de las flores (Diptera: Syrphidae) en Salvia bogotensis (Lamiaceae) en el jardín botánico José Celestino Mutis. Bogotá, D.C., Colombia. Caldasia 33(2): 453-470.

Zamudio, S. and B. Y. Bedolla-García. 2018. Salvia madrigalii (Lamiaceae), una especie nueva de Michoacán, México. Brittonia 70: 76-83. DOI: https://doi.org/10.1007/s12228017-9491-3

Zavortink, T. J. and S. S. Shanks. 2008. Anthidium manicatum (Linnaeus) (Hymenoptera: Megachilidae) in California. The Pan-Pacific Entomologist 84(3): 238-241. DOI: https://doi. org/10.3956/2007-47.1 